\title{
A crise e a política de CT\&I na América Latina
}

Renato Dagnino*

Meu interesse de avaliar o binômio risco-oportunidade que a atual crise do capitalismo coloca para a orientação da política de CT\&I (PCTI) em curso na América Latina, e que se caracteriza pelo aumento da subvenção à $P \& D$ na empresa privada, me faz iniciar com um comentário sobre o caráter desta crise. Depois indico aspectos que ele desvela e que parecem sugerir a necessidade de um encaminhamento bastante distinto do proposto.

Segundo divulgado pela mídia, a origem da crise parece se localizar nos mercados financeiros dos países centrais. Focada no seu sintoma financeiro, sua manifestação mais evidente, essa interpretação não atenta para os aspectos econômico-produtivos, mais ligados ao plano da PCTI que é necessário destacar.

Para fazê-lo começo assinalando que estamos frente a uma crise capitalista clássica, de realização do valor. Uma crise devida à impossibilidade de realizar o valor gerado no interior do sistema, amplificada por aspectos econômico-produtivos associados ao processo de globalização e interpenetração dos mercados. Compreender sua verdadeira origem descortina um panorama acerca dos aspectos relacionados à política produtiva e à PCTI que revela a necessidade de sua urgente inflexão.

Esta crise foi "chocada" nos últimos 30 anos pela incorporação ao mercado mundial de 1,2 bilhão de operários de baixos salários dos países da antiga União Soviética, da Índia e, principalmente, da China. O diferencial de salário deles em relação aos operários alemães (de 30 dólares por hora) é, no caso dos chineses (de 60 centavos) de 50 vezes! De fato, das três bilhões de pessoas que atualmente trabalham no mercado global, metade ganha menos de três dólares por dia.

O fato da remuneração do trabalhador ser tão baixa nesses países (ou, no caso chinês, ser subestimado na contabilidade das empresas exportadoras que registram como salário algo bem inferior ao que no capitalismo é o custo de reprodução da força de trabalho) ao mesmo tempo em que barateia seu preço internacional impede que as mercadorias que produzem sejam lá compradas. Na verdade, grande parte do que é exportado, ao contrário até

\footnotetext{
* Pós-Doutor em Estudos Sociais da Ciência e Tecnologia pela Universidade de Sussex, doutor em Ciências Econômicas pela UNICAMP. Professor Titular no Departamento de Política Científica e Tecnológica da UNICAMP. Endereço eletrônico: rdagnino@ige.unicamp.br.
} 
mesmo do que ocorreu nas economias não-planificadas do Japão e da Coréia do Sul há décadas atrás, foi desde o início produzido visando o mercado dos países avançados.

Esse novo estilo de competição encontra na China sua quintessência, onde se alia uma intervenção ("socialista") do Estado, que desconecta o salário do valor da força de trabalho e que promove a inovação segundo padrões capitalistas que favorecem um downgrading custo-efetivo programado. O qual se revela quando usamos aquelas mercadorias. Países que não possuem um Estado capaz de engendrar uma situação tão "perfeita" não têm obtido resultado tão marcante.

Um dos resultados desse movimento foi, por um lado, o barateamento do custo de reprodução da força de trabalho nos países avançados. Mas como era de se esperar, muitos dos que trabalhavam nos setores agora não mais competitivos em função desse novo estilo de competição perderam seus empregos e salários.

Por outro lado, e ao mesmo tempo em que o aumento da concentração de renda ia incubando uma crise de realização no centro do sistema, o lucro da venda das mercadorias provenientes dos países de baixos salários ia a ele retornando; o que não é novo para quem se lembra dos petrodólares que se transformaram em eurodólares na década dos setenta.

Como se sabe, a China tem mais de um trilhão de dólares aplicado em títulos do governo estadunidense. Dólares que permitiram retardar a eclosão da crise através do financiamento do Tesouro e que hoje são "cobrados" através da pressão que ela exerce para que o governo estadunidense solucione a crise. Solução essa que, animada por um espírito nacionalista-estatista que desfaz os mitos da globalização e da mão invisível propalados pelo neoliberalismo, se traduz em medidas de favorecimento as suas classes proprietárias.

Essa interpretação da crise evidencia pelo menos quatro aspectos importantes para refletir sobre a necessidade de reorientação da PCTI latino-americana.

O primeiro, é que o considerável esforço de investimento em P\&D e em capacitação realizado nos países avançados para expandir os segmentos intensivos em conhecimento não foi suficiente para que eles se defendessem da competição que implicava a nova divisão internacional do trabalho. E, dessa maneira, pudessem evitar a crise. $\mathrm{Na}$ verdade, a lição dos neo-schumpeterianos que observaram o cenário tecnológico-produtivo dos anos 70, que a partir da Ásia colocara pressões competitivas inéditas, parece não ter sido bem assimilada.

O que serve de alerta para aqueles que - interessada ou ingenuamente - propõem que se adote na América Latina uma estratégia semelhante. Nossa estrutura industrial concentrada em segmentos de baixa intensidade tecnológica, com baixa capacidade de inovação e 
baixíssima propensão a realizar $\mathrm{P} \& \mathrm{D}$, e sua pesquisa científica pouco relacionada à produção industrial, não nos qualificam como candidatos nessa competição.

O segundo aspecto é que o principal mercado para as mercadorias produzidas nos países de baixos salários com aquele novo estilo de competição tende a se reduzir em função da deterioração do padrão de vida dos assalariados dos países avançados.

O que torna a fronteira de expansão até agora perseguida pela indústria latinoamericana em função de sua especialização nesses produtos, ainda mais difícil de ser explorada. A menos que estejamos dispostos a agravar o apartheid social e econômico em que vivemos fazendo com que o salário do trabalhador - no caso brasileiro, de 4,50 dólares por hora - se aproxime do que é contabilizado como valor de reprodução da força de trabalho chinesa. Uma estratégia como essa não é apenas socialmente suicida; como se sabe, foi justamente o movimento contrário ensaiado no campo das políticas públicas dos últimos anos o responsável pela relativa proteção que países como o Brasil hoje goza em relação à crise mundial.

O terceiro, é que no nosso caso existe um mercado potencial grande para aquele tipo de produtos e que cresce com a política de redução da pobreza em curso. Eles têm sido produzidos com tecnologias duplamente inadequadas. Por um lado, dado que nãocompetitivas, para o mercado externo. Por outro, dado que, além disto, são incompatíveis com a criação de oportunidades de trabalho (que pelas razões conhecidas não serão oportunidades de emprego em empresas privadas) e renda que a política de inclusão social tenciona alavancar, para a nação.

Essa constatação abre uma fronteira de inovação com desafios quantitativos, dado a dimensão do mercado interno (e também externo passível de exploração) das famílias e, indiretamente, do Estado. E qualitativos, dado a originalidade imposta pelos requisitos sociais, econômicos e ambientais. Novos objetivos terão que ser atendidos pela PCTI. A sua agenda decisória, como também a agenda de pesquisa da comunidade científica, terá que ser alterada. E, no campo tecnológico-produtivo, novos atores (como os empreendimentos da Economia Solidária) terão que ser incorporados aos processos de inovação e de produção dos bens e serviços que a materialização desse cenário implica.

A tendência ao desemprego e à precarização do trabalho que faz com que hoje quase $60 \%$ da nossa força de trabalho esteja à margem do mercado formal se está agudizando; inclusive em função do oportunismo dos empresários que "desovam" desemprego tecnológico programado aproveitando a crise. O que torna ainda mais urgente a inflexão da 
PCTI no sentido do que tem sido denominado Tecnologia Social - a tecnologia alternativa àquela produzida pelas e para as empresas privadas - demandada para tornar sustentáveis os empreendimentos da Economia Solidária.

O quarto aspecto tem a ver com a dimensão ecológica, que sinaliza que uma crise de proporções muitíssimo maiores e que contém um desafio tecno-científico enorme. Hoje a população mundial consome $40 \%$ mais recursos do que a Terra consegue repor. E com um crescimento anual de 2 a 3\% vamos precisar em 2040 duas Terras para atender a demanda. A atual crise é vista por muitos como uma crise terminal do modo de produzir capitalista. Para lograr um estilo de desenvolvimento alternativo - não baseado na exploração ilimitada de uma natureza limitada e de uma sociedade cujos limites de tolerância estão também a se esgotar temos que incorporar a ecologia como dimensão estratégica da PCTI.

É claro que as características de uma política-meio como a PCTI, em especial aquelas que emergem dos aspectos apontados demandam políticas-fim capazes de alterar o estilo de desenvolvimento até agora adotado e contribuir para modificar a relação de forças políticas vigente. E é claro também que o papel do governo, à semelhança do que ocorreu no Brasil (crise de trinta, "cinquenta anos em cinco", "industrialização pesada") quando conjunturas no mercado mundial alavancaram políticas agressivas, é fundamental. Há agora a possibilidade de que as alianças que materializem esse novo ciclo de investimentos não sejam feitas "por cima". E que os aliados não sejam buscados dentre aqueles que têm sido sempre os beneficiados dos ciclos anteriores e, em geral, das políticas públicas. 